\title{
Effective and productive use of information technologies in the library sector: towards a transformative approach to sustainable development
}

\author{
Aliyu Musa \\ Muhammadu Wabi Library, Federal Polytechnic, Bauchi, Nigeria
}

\begin{abstract}
Although there is an increasing use of emerging technologies in the Library sector in higher education internationally and in Nigeria in particular, there is little evidence that it is used in transforming teaching and learning practice. Teaching and learning would have been more user friendly, with multiple positive recompense and positive feedback mechanism if emerging technologies are adequately put to use. Thus, the gap between technologies supported and used for teaching and the technologies used by students for learning has created pressure for educators and policy makers to come out with an up-to -date transformative approach towards effective and productive use of emerging technologies with a view to transform the education sector and encourage the use of emerging technologies in the library division. This paper seeks to highlight the available technologies in the sector and how to positively explore them. ICT and other sectors of the economy will also not be left out. It will also proffer a transformative approach on how such technologies can be utilized to the maximum for the benefit of teaching and learning and policy makers in particular, and the country's other sectors at large. The paper draws its data from Secondary source only.
\end{abstract}

Keywords: Library; information technology; education; transforming teaching

\section{INTRODUCTION}

In programming, a library is a collection of precompiled routines that a program can use. The routines, sometimes called modules, are stored in object format. Libraries are particularly useful for storing frequently used routines because you do not need to explicitly link them to every program that uses them. The linker automatically looks in libraries for routines that it does not find elsewhere. A building or room containing collections of books, periodicals, and sometimes films and recorded music for people to read, borrow, or...A collection of books and periodicals held in such a building or room. It is an organized collection of information resources made accessible to a defined community for reference or borrowing. It provides physical or digital access to material, and may be a physical building or room, or a virtual space, or both. A library's collection can include books, periodicals, newspapers, manuscripts, films, maps, prints, documents, microform, CDs, cassettes, videotapes, DVDs, Blu-ray Discs, e-books, audio books, databases, and other formats. Libraries range in size from a few shelves of books to several million items.

A library is organized for use and maintained by a public body, an institution, a corporation, or a private individual. Public and institutional collections and services may be intended for use by people who choose not to - or cannot afford to - purchase an extensive 
collection themselves, who need material no individual can reasonably be expected to have, or who require professional assistance with their research. In addition to providing materials, libraries also provide the services of librarians who are experts at finding and organizing information and at interpreting information needs. Libraries often provide quiet areas for studying, and they also often offer common areas to facilitate group study and collaboration. Libraries often provide public facilities for access to their electronic resources and the Internet. Modern libraries are increasingly being redefined as places to get unrestricted access to information in many formats and from many sources. They are extending services beyond the physical walls of a building, by providing material accessible by electronic means, and by providing the assistance of librarians in navigating and analyzing very large amounts of information with a variety of digital tools.

There is no doubt that Information and Communication Technology has found its niche in every sphere of Nigeria's polity. Information and Communication Technology has been defined as "a broad based technology (including its methods, management and application) that supports the creation, storage, manipulation and communication of information" (French, 1996). According Hang and Keen in Nworgu (2007), information technology means a set of tools that helps you work with information and perform tasks related to information processing". The definition of French is more encompassing than that of Nworgu, which was limited to information processing and did not extend to the communication of ICT. Actually, the term originated as Information Technology (IT) until recently when it was thought that the communication component ought to be highlighted because of its significance. It was then that the concept transformed to Information and Communication Technology ICT (Olusanya and Oleyede, 2003).

The ICT industry according to Nworgu (2007) appears to be making significant in road into the Nigeria society. Prior to 1999, ICT resources and facilities were grossly limited in the country. Only very few wealthy Nigerians had access to these facilities and services. Internet facilities and services were rare to come by and the facsimile (ie. Fax) remained for a long time, the only means available to Nigerians for transmitting and receiving data or documents to other parts of the world. Public awareness of ICT and its application was low.

But now, the picture is entirely different. Huge investments have been made by both the public and private sectors in the ICT business in the country. Within the last three (3) years, the country has witnessed tremendous expansion in ICT resources and facilities. About 70 million Nigerians now have access to GSM. With the liberalization policy of the Federal Government, more GSM operators and Internet Service Providers (ISPs) have been licensed and are now operating in the country. Millions of Nigerians now have access to these facilities and services even in the rural communities.

A significant milestone in the development of the ICT industry in the country is the formulation of a National Information Technology Policy (NITP), which was approved in March, 2001 by the Federal Executive Council. With the enactment of this policy came the establishment of an implementing agency-the National Information Technology Development Agency (NITDA) in April 2001. This agency is charged with the responsibility of implementing Nigeria 's IT policy "as well as promote the healthy growth and development of the IT industry in Nigeria (Isoun, 2003).

* Alleviation of uncertainty. According to Mark and Pierce (2001), Shannon, as long ago as 1948, defined information as the resolution of uncertainty. This is perhaps one of the intangible attributes best known among a variety of researchers.

* Interdependency. Information almost always forms part of technology - it is the "soft" part (Röling 1990: 12). Without its information component, technology has little value as a 
resource for potential users who are not familiar with its workings or its background. With regard to developing rural communities, one should bear in mind that it is not necessarily new technology that brings about these achievements. All outside technology applied for the first time could be viewed as new to the user group or that particular situation, and could have similar effects.

* Enhancement of economic growth. A frequent complaint is that information is often denied its role as a resource (Neelameghan 1980; Boon 1992). Yet, when looking at the effect of information in development situations, there seems to be an underlying awareness of its importance. Kaimowitz et al., (1990: 238) refer to the impact of new technology (including information as the hidden component) in agriculture on the basis of such aspects as increased farm income, reduced risk, resource conservation, improved health, better (food) security, and overall economic growth.

* Extension of the knowledge base. From a development point of view, there is more emphasis, first, on improving peoples' lives socially, and only secondly on economic improvement. In development, outside technology is often introduced with the help of education, training and visual demonstrations. Rogers (1992: 137) states that training helps people in rural communities to expand horizons, increase perceptions, enhance competencies, enlarge sense of perspective, and enhance self-esteem.

The above seem to emphasise the impact of the dynamic force of information, where the 'extension or altering of people's stores of knowledge' (Eaton \& Bawden 1991) positively affected their social well-being. Thus, although information is an intangible entity, it has the ability to bring about change for the better; which is the ultimate goal of development.

\section{AVAILABLE TECHNOLOGIES IN THE LIBRARY SECTOR FOR SUSTAINABLE DEVELOPMENT}

According to Attama and Owolabi (2008)the following are primary ICT resources,

1. Computers: Computers are no longer just mathematical tools but essential management resources. As we all may know, different operations can be handled more efficiently using Computers. With the computer, such activities as information generation, processing, analyzing, storage and communication for sustainable development could be executed easily. The greatest assets of the computer are speed, cost-effectiveness and optimal utilization of available resources. Some other computer accessories worthy of mentioning are CD.ROM, diskettes, flash drive, etc.

2. The Internet: This has proven to the most valuable vehicle for accelerated information flow. According to Ogbomo (2004), it is a network of computers that communicate with each other, often over telephone lines. The potentials of the internet lies in the provision of global platform for information sharing among organizations and individuals. Information sharing creates awareness, ensures continuous use of products and services, provides feedback and support for organization. The contention here is that any organization or government that has current and useful information is empowered to enhance productivity and good governance.

3. Electronic Mail (E-mail): This is the most widely used resource of the Internet. It is provided for sending and receiving mails (messages) through electronic devices. Intra and inter organizational communication has been made faster and cheaper. E-mail has become the life-wire for many business and organizational communication. 
4. World Wide Web (WWW): World Wide Web is also an Internet-based resource. It is a utility based on hypertexts (Hypertexts simply documents through keywords in document or page). A visit to a website helps individuals or organization to locate products, information, pursues political or social agenda and transacts business (Chilvetalu, 2003). From the above, we can infer that being on the web would put any nation or organization on the right course of speedy and sustainable development in line with the emerging changes in technology, economic and political paradigms. Consequently, many organizations, ministries and parastatals in Nigeria have their own websites through which they make relevant information available to members of the public.

\section{BENEFITS OF ICT TO THE LIBRARY AND OTHER SECTORS}

The importance of ICT to different sectors of national, economic and educational life of the nation cannot be over stressed. The specific benefits of ICT to these sectors and how the use has been contributing to sustainable national development are discussed under this segment.

\section{ICT FOR GOOD GOVERNANCE}

The potential attributes and benefits of ICT to policy makers in the society have been accepted as imperative paradigm (Attama and Owolabi, 2008). In all intents and purposes, ICT is the acclaimed engine room of modern day global development and sustainable growth (United Nations Conference on Trade and Development, 2005). In the same vein, Anehobi (2007) maintains that no institution or organization can still rely only on the traditional printed information resources to perform efficiently.

The infusion of ICT into public administration enhances efficiency in the delivery of services to the people. Heber (1990) in his own view maintains that ICT helps in taking high quality decisions and at the same time saves time. It is in line with the laudable roles that the federal government of Nigeria in order to ensure the full exploitation of the potentials of ICTs in sustainable democracy laid foundation for e-government in Nigeria (Aragba-Akpore, 2004).

Countries that have adopted and applied electronic services (ICT) to their operations have witnessed dramatic improvement in their development efforts. For countries such as Singapore, United States, Canada, Japan and most European nations, ICT is a strong tool for sustainable development and improving governance, widening democratic space, increasing productivity, administrative effectiveness and cost savings (Adamali, Coffey and Safdar, 2006). It is not surprising therefore that the application of ICT in governance is engendering much concerns in many countries of the world.

\section{ICT APPLICATION IN EDUCATION}

Most of the discussions and initiatives on ICT in Education tend to focus on the use of ICT for teaching and learning only (The Commonwealth of Learning, 2006; Becta, 2004; Akale, 2003). This emphasis on instructional applications of ICT in education has an antecedent. From the earliest times, educational interest in technology has always centred on the instructional application of such technology to improve teaching and learning. The case of 
the computer provides a perfect illustration of this point. Long before the emergency of ICT, educational interest in the computer centred on its instructional applications as exemplified by computer-assisted instruction (CAI), computer-aided testing (CAT), etc.

It is perhaps easy to understand why the emphasis at the basic and secondary education levels should exclude research application of ICT. The primary responsibility of the teachers at these levels is defined exclusively in terms of teaching. However at the higher education level, teachers"primary responsibility is of a tripartite nature involving teaching, research and community service. In effect it can be suggested here that any approach to ICT adoption at the higher education level that stressed only instructional applications and ignores research applications, will be grossly inadequate in meeting the needs of both students and teachers:

The indispensability of ICT in education research in particular includes

- Learning how to optimize the creativity of African Scientists through participation in international networks and working with data sets.

- Accessing various kinds of research information, which would necessitate a link to the libraries group

- Learning new methods for disseminating knowledge produced in Africa and using them.

- ICT applications run through the entire gamut of the educational research process. The advocacy for the indispensability of ICT in educational research can be further strengthened by the following arguments that tend to underscore the values derivable from applying ICT in educational research.

- It reduced time and cost of conducting educational investigation.

- Data sets and library resources can be shared by institutions in different locations

- Educational researchers have easy access to current literature materials

- Data sets, irrespective of size can be stored and retrieved when needed.

- Researchers in different locations can collaborate more easily, etc (Nworgu, 2007) Ijafuyi and Adebanjo (2006) while speaking on the usefulness of ICT in sustainable development advised on the need for a well-equipped ICT centres in all educational institutions to enable them live up to their social and political responsibilities.

\section{BENEFITS OF ICT IN LEGAL SYSTEM}

Globalization driven by ICT is having a phenomenal impact on acquisition of legal, and other relevant learning, teaching and research materials in law libraries across the country. Through ICT, lawyers and students can have access to current court proceedings/cases and law reports anywhere, any time and in any form in the country.

There is no doubt that the integration of ICT into the practice of law is of much benefit to the profession in Nigeria in the 21 st century. ICT is a remarkable tool for providing comprehensive, current and timely legal services to the citizenry. (Okon and Bassey, 2008). The relevance of ICT adoption and utilization in Nigerian legal system for effective and efficient service delivery is a contributory factor to sustainable development in Nigeria. 


\section{ICT IN BUSINESS MANAGEMENT}

Information and Communication Technology (ICT) is an essential part of national infrastructure and factors greatly in both public and private sector business enterprises. It creates business opportunities, especially for companies located far from urban centres, and improves links among firms, suppliers and clients. When used well, ICT can also make management and operation more efficient.

In another development, Sangowusi cited by Attama and Owolabi (2008) maintains that ICT is very useful in corporate environment because it promotes performance and improves efficiency.

\section{TRANSFORMATIVE APPROACH IN THE LIBRARY SECTOR-A WAY OUT}

* Creation of a talent forum to ensure succession planning across departments for Senior Civil Service ICT vacancies;

* Establishment of a streamlined selection process for the Technology in Business Fast Stream, enabling a larger intake to be assessed;

* Development of a Career Paths Framework to enable staff to plot and drive their own careers and enable organizations to move ICT staff across government to fill vacancies, reducing reliance on external contractors;

* a draft model for the functions required for retained ICT capability enabling a clear picture of the essential skills required; and

* a proposal for ICT Higher Level Apprentices working with industry and eSkills. This scheme will be a joint public/ private sector initiative leading to an opportunity for candidates to gain a work based qualification and experience working in Government ICT.

* Making government ICT more open to the people and organizations that use our services, and open to any provider - regardless of size;

* Reducing the size and complexity of projects, and better manage risks;

* Enabling reuse of existing ICT systems and 'off the shelf' components, reducing duplication, over-capacity and saving money;

* Moving towards a common infrastructure in government, increasing efficiency and interoperability;

* Reducing procurement timescales and making it easier and simpler for SMEs to compete for government business, supporting the aspiration that $25 \%$ of Central Government procurement spend should go to SMEs by the end of this Parliament (2015); and

* Improving the implementation of big ICT projects and programmes, and supporting the IT profession in government and the public sector.

\section{SUMMARY AND CONCLUSION}

It has been commonly accepted and proven that information and communication technology (ICT) is the engine of the 21 st century and beyond; as it will chart the economic, religious, cultural, legal and social life of nations, particularly that of developing countries (Ukodie, 2004). Hence, according to Nkereuwem (1996), the importance of information and communication technology for sustainable development, has long been recognized by developing countries. ICT has impacted on different sectors of the Nigerian economy. The 
application of ICT has emerged as the most radical development of the 21 st century. It has facilitated speedy information transmission, high level decision making, reduces cost in resources/organizational management and as well opens vast opportunities for information sharing among individuals, companies and governmental institutions. It is a truism that information and communication technology (ICT) is very indispensable to Nigeriah sustainable development drive. Today, ICT has been successfully integrated in the process of state administration, leading to a view concept of e-government. The potential benefits of ICT to sustainable development in Nigeria has been accepted as an imperative paradigm.

* Alleviation of uncertainty. According to Mark and Pierce (2001), Shannon, as long ago as 1948, defined information as the resolution of uncertainty. This is perhaps one of the intangible attributes best known among a variety of researchers.

* Interdependency. Information almost always forms part of technology - it is the "soft" part (Röling 1990: 12). Without its information component, technology has little value as a resource for potential users who are not familiar with its workings or its background. With regard to developing rural communities, one should bear in mind that it is not necessarily new technology that brings about these achievements. All outside technology applied for the first time could be viewed as new to the user group or that particular situation, and could have similar effects.

* Enhancement of economic growth. A frequent complaint is that information is often denied its role as a resource (Neelameghan 1980; Boon 1992). Yet, when looking at the effect of information in development situations, there seems to be an underlying awareness of its importance. Kaimowitz et al., (1990: 238) refer to the impact of new technology (including information as the hidden component) in agriculture on the basis of such aspects as increased farm income, reduced risk, resource conservation, improved health, better (food) security, and overall economic growth.

* Extension of the knowledge base. From a development point of view, there is more emphasis, first, on improving peoples' lives socially, and only secondly on economic improvement. In development, outside technology is often introduced with the help of education, training and visual demonstrations. Rogers (1992: 137) states that training helps people in rural communities to expand horizons, increase perceptions, enhance competencies, enlarge sense of perspective, and enhance self-esteem.

The above seem to emphasize the impact of the dynamic force of information, where the 'extension or altering of people's stores of knowledge' (Eaton \& Bawden 1991) positively affected their social well-being. Thus, although information is an intangible entity, it has the ability to bring about change for the better; which is the ultimate goal of development.

* Context dependency. The value of information as a resource in rural development depends largely on situation-specific issues: for example, one could argue that agriculturerelated information is mostly technical in nature. However, people with little exposure to modern society have many related issues they need to know about. Ozowa (1995: 17), for example, identified certain types of basic information needed for the development of crop production by traditional farmers; inter alia, information about agricultural input (seeds, fertiliser, etc.), extension, technology (farming equipment, etc.), implementation techniques (ploughing, sowing, pest and weed control), soil, water and climatic conditions, conservation, credit, marketing and infrastructure. 
* Culture dependency. Another attribute of information that can influence its usefulness as a development resource is that it is culture dependent - involving conceptual and cognitive differentiation. Pickering (1996: 451) is of the opinion that because information is culture specific, it is incommunicable unless acculturated - that is, adapted for the cultural environment or the cultural mind-set of the recipient group. Here, Shields and Servaes (1989: 49) also point out that information is not totally value-free, but is socially conditioned and shaped by the social structures that apply it. This aspect has serious implications for developers' efforts to transfer information to the rural communities of developing countries.

* Medium dependency. Information is not only culture dependent, but also medium dependent. Once information is concretized outside the human memory it should be packaged in some or other format (i.e., print, images, sound, electronic digits, etc..) to be communicated to someone else. Unless receivers know how to use that particular format, the information will remain inaccessible and rendered useless; for example, an electronic medium directed at users who are unfamiliar with such facilities can impede access to available information.

\section{References}

[1] Hester W.J. Meyer (2005). The nature of information, and the effective use of information in rural development. Vol. 10 No. 2, January 2005 Department of Information Science, University of South Africa, Pretoria, South Africa

[2] Adamali, A. Coffey, J. O., \& Safdar, Z (2006). Trends in national e-strategies: A review of 40 countries. In the World Bank Information and Communication for development: Global trends and policies. Washington DC: The World Bank.

[3] Becta, H. (2004). Enabling Teachers to make successful use of ICT. http://ww.becta.org.uk.

[4] Chiwetalu B. N., Nigerian Journal of Unity and Development 2(1) (2003) 24-27.

[5] Ukodie, A. (2004). Ekuwem: Nigerian striking force: Icons of ICT in Nigeria: Their passion, vision, thoughts. Lagos: ICT Publications.

[6] United Nations Conference on Trade and Development (2005). Information Economy report 2005. New York: United Nations.

[7] Ogbomo, M. O. (2004). Web page design. In E. C. Madu (Ed). Technology for Information Management and Service: Modern libraries and Information centres in developing countries. Ibadan: Evi-Coleman.

[8] Nkereuwem E. E., Library Management 17(5) (1996) 25-30.

[9] Nworgu, B. G. (2007). The Indispensability of ICT in Educational Research in Information Communication Technology in the Service of Education Ed. By D. N. Ezeh and Nkadi Onyegegbu. Enugu: Timex.

[10] Okon E. A.,Bassey A. B., Nigerian Law Libraries for Sustainable Development. H-Jolis 2(1\&2) (2008) 141-152.

[11] Attama R. O., Owalabi K. A., Nigerian Library Link 6(1) (2008) 35-44

[12] Olorundare S. (2007). Utilization of Information and Communication Technology (ICT). in Curriculum Development, Implementation Technology in the Service of Education ed. By D. N. Ezeh and Nkadi Onyegegbu. Enugu: Timex. 
[13] Olusanya, O. M. \& Olayede, O. I. (2003). Effective Utilization of Information and Communication Technology (ICT). for boosting Research in Science, Technology and Mathematics Education in Nigeria in M.A.G. Akale (Ed). Proceedings of the 44th Annual Conference of Science Teachers Association of Nigeria.

[14] Parkash Chandra Jena, Latif Ahmad, International Letters of Social and Humanistic Sciences 9 (2013) 1-10

[15] Borowski A., International Letters of Social and Humanistic Sciences 11 (2013) 100-105

[16] Liverpool E. Onyije, Jacinta A. Opara, International Letters of Social and Humanistic Sciences 1 (2014) 81-87.

[17] Sele Sylvester Ebisin, International Letters of Social and Humanistic Sciences 2 (2014) $1-9$.

[18] Tittenbrun J., International Letters of Social and Humanistic Sciences 2 (2014) 20-40.

[19] Alaba E. Dare, International Letters of Social and Humanistic Sciences 3 (2014) 73-79.

[20] Azuh Oluchi Jannet, Melody Ndidi Modebelu, International Letters of Social and Humanistic Sciences 2 (2014) 88-96.

[21] Philip Usman Akor, Julie Udensi, International Letters of Social and Humanistic Sciences 2 (2014) 97-109.

[22] Borowski A., International Letters of Social and Humanistic Sciences 2 (2014) $110-121$

[23] Adoga James Ada, International Letters of Social and Humanistic Sciences 3 (2014) 45-52.

[24] Grema Maina Bukar, Yohanna A. Timothy, International Letters of Social and Humanistic Sciences 4 (2014) 9-21.

[25] Elijah Akwarandu Njoku, Patrick Etim Akpan, International Letters of Social and Humanistic Sciences 4 (2014) 22-30.

[26] Onyike Maggaret Odu, International Letters of Social and Humanistic Sciences 4 (2014) 31-39.

[27] M. N. Modebelu, F. K. Igwebuike, International Letters of Social and Humanistic Sciences 4 (2014) 40-48.

[28] Akor Isaiah Akem, Victor Tavershima Ukeli, International Letters of Social and Humanistic Sciences 4 (2014) 49-59.

[29] Akpoyovwaire Samuel Mukoro, International Letters of Social and Humanistic Sciences 4 (2014) 60-70.

[30] Israel Sunday Udoka, International Letters of Social and Humanistic Sciences 4 (2014) 71-86.

[31] Sule Maina, International Letters of Social and Humanistic Sciences 4 (2014) 87-96. 
[32] Nwachukwu Uche Emma, International Letters of Social and Humanistic Sciences 5 (2014) 1-12.

[33] Okezie A. Ihugba, Alex Odii, A. C. Njoku, International Letters of Social and Humanistic Sciences 5 (2014) 21-34.

[34] Okezie A. Ihugba, Bankoli Bankong, N. C. Ebomuche, International Letters of Social and Humanistic Sciences 5 (2014) 92-113. 